Info Artikel Diterima Desember 2020

Disetujui Februari 2021

Dipublikasikan April 2021

\title{
PENGARUH BERBAGAI JENIS PUPUK KANDANG DAN \\ KONSENTRASI PLANT GROWTH PROMOTING RHIZOBACTERIA \\ (PGPR) TERHADAP PERTUMBUHAN DAN PRODUKSI CABAI \\ (Capsicum annum L.)
}

\section{THE EFFECT OF VARIOUS TYPE OF MANURE AND PLANT GROWTH PROMOTING RHIZOBACTERIA (PGPR) ON THE GROWTH AND PRODUCTION OF CHILI (Capsicum annum L.)}

\author{
Erlin Wahyu Nur Khasanah ${ }^{1}$, Eny Fuskhah, Sutarno \\ Program Studi Agroekoteknologi, Departemen Pertanian \\ Fakultas Peternakan dan Pertanian Universitas Diponegoro \\ Jl. Prof. Soedarto, Tembalang Kota Semarang 50275 \\ Email $^{1}$ : erlinwahyu01@gmail.com
}

\begin{abstract}
Chili is an important horticultural commodity in Indonesia. Chili widely cultivated by farmers because of its high selling price and market demand. Stabilization is needed to increase production so that the demand for chili can be fulfilled. Several effort to increase production of chili is completing plant nutrient. Application of manure can provide nutrient that plants need without affect to soil if it use in longterm. Biofertilizer such as PGPR can increase effectiveness ofmanure. Combination of manure and PGPR can used to be alternative to increase the soil fertility, growth, and production of chili. This research was conducted on March-July 2020 in Green House and Laboratory of Ecology and Plants Production, Faculty of Animal Husbandry and Agriculture, Diponegoro University, Semarang. This research was arranged on completely randomized design factorial $3 \times 5$ with 3 replication. First treathments are chicken manure(P1), cow manure(P2), and goat manure(P3). Second treathments are control/0 ml/liter (B0), commercial PGPR $5 \mathrm{ml} /$ liter (B1), PGPR $5 \mathrm{ml} /$ liter (B2), PGPR 12,5 ml/liter (B3), and PGPR $20 \mathrm{ml} / \mathrm{liter}$ (B4). Data was analyzed with analysis of variance (ANOVA). The further analysis using duncan multiple range test. The result showed that the treatment of manure has an effect on variable of plant height, weight of fruit per plant, number of fruit per plant, fresh weigth of the plant production of canopy dry material, and production of root dry materials. Consentration of PGPR treathments and interaction between type of manure and PGPR can't take effect to all of observation variables.
\end{abstract}

Keywords: Chili, Manure, PGPR, Growth, and Development.

\section{ABSTRAK}

Cabai merupakan komoditas hortikultura penting di Indonesia. Cabai banyak dibudidayakan karena memiliki harga jual dan permintaan pasar yang tinggi. Perlu adanya stabilisasi untuk meningkatkan produksi cabai sehingga 
kebutuhan cabai dapat terpenuhi. Beberapa usaha untuk meningkatkan produksi cabai yaitu pemenuhan unsur hara tanaman. Pemberian pupuk kandang mampu membantu menyediakan hara yang dibutuhkan tanaman cabai tanpa merusak tanah jika digunakan dalam waktu panjang. Peningkatan efektifitas pupuk kandang dapat dilakukan dengan penambahan biofertilizer seperti PGPR. Kombinasi pupuk kandang dan PGPR dapat dijadikan alternatif untuk meningkatkan kesuburan tanah, pertumbuhan, dan produksi tanaman cabai. Penelitian dilaksanakan pada bulan Maret sampai dengan Juli 2020 di Green House dan Laboratorium Ekologi dan Produksi Tanaman, Fakultas Peternakan dan Pertanian, Universitas Diponegoro, Semarang. Penelitian menggunakan rancangan acak lengkap pola faktorial 3x5 dengan 3 ulangan. Faktor pertama (P) yaitu pupuk kandang ayam (P1), pupuk kandang sapi (P2), pupuk kandang kambing (P3). Faktor kedua (B) terdiri dari kontrol/0 ml/liter (B0), PGPR komersial $5 \mathrm{ml} /$ liter (B1), PGPR $5 \mathrm{ml} /$ liter (B2), PGPR 12,5 ml/liter (B3) dan PGPR $20 \mathrm{ml} /$ liter (B4). Data yang diperoleh dianalisis menggunakan analisis ragam (ANOVA). Uji lanjut yang digunakan yaitu uji jarak berganda duncan. Hasil penelitian menunjukkan perlakuan pupuk kandangmemberikan pengaruh pada variabel tinggi tanaman, bobot buah per tanaman, jumlah buah per tanaman, berat segar tanaman, produksi bahan kering tajuk, dan produksi bahan kering akar. Perlakuan konsentrasi PGPR serta interaksi antara jenis pupuk kandang dan konsentrasi tidak berpengaruh pada semua variabel pengamatan.

Kata kunci : Cabai, Pupuk Kandang, PGPR, pertumbuhan, dan produksi.

\section{PENDAHULUAN}

Cabai merah (Capsicum annum L.) merupakan tanaman perdu dari famili solanacae (suku terong-terongan). Cabai adalah salah satu komoditas hortikultura yang banyak dibudidayakan oleh petani di Indonesia, karena memiliki harga jual yang tinggi dan memiliki beberapa manfaat bagi kesehatan. Tanaman cabai memiliki daya adaptasi yang cukup luas, dapat tumbuh pada dataran rendah hingga dataran tinggi, baik di lahan sawah maupun lahan kering. Untuk mendapatkan hasil dan produksi cabai yang tinggi perlu memerhatikan teknik budidaya, ketersediaan hara dalam tanah, kondisi lingkungan, serta serangan hama dan penyakit.

Salah satu hal penting yang perlu diperhatikan dalam budidaya tanaman cabai yaitu pemupukan. Pemupukan untuk tanaman cabai sesuai rekomendasi serta kebutuhan hara tanaman cabai yaitu $200 \mathrm{~kg}$ N/ha, $150 \mathrm{~kg}$ P2O5/ha dan 150 $\mathrm{kg} \mathrm{K} 2 \mathrm{O} / \mathrm{ha}$ (Balitsa, 2007). Pemberian pupuk kandang dapat memperbaiki sifat fisik, kimia, dan biologi tanah, serta mempengaruhi pertumbuhan tanaman. Unsur hara pupuk kandang bervariasi namun kadarnya cukup rendah dan lambat tersedia bagi tanaman. Aspek penting dalam keseimbangan unsur hara total adalah rasio organik karbon dengan nitrogen (Rasio $\mathrm{C} / \mathrm{N}$ ). Rasio $\mathrm{C} / \mathrm{N}$ merupakan perbandingan antara banyaknya kandungan unsur karbon (C) terhadap banyaknya kandungan unsur nitrogen $(\mathrm{N})$. Nilai rasio $\mathrm{C} / \mathrm{N}$ berbanding terbalik dengan ketersediaan unsur hara yang dapat diserap tanaman. Untuk mempercepat pelepasan hara dalam pupuk kandang, maka perlu dilakukan pengomposan agar rasio $\mathrm{C} / \mathrm{N}$ menurun. 
Menurunnya rasio $\mathrm{C} / \mathrm{N}$ dalam suatu bahan menunjukkan bahwa ketersediaan nitrogen dari bahan tersebut untuk diserap tanaman akan meningkat (Widarti et al., 2015). Mikroorganisme memerlukan karbon dan nitrogen untuk aktivitas hidupnya. Rasio $\mathrm{C} / \mathrm{N}$ dari suatu bahan organik yang terlalu tinggi menyebabkan proses dekomposisi bahan organik berlangsung lebih lambat, keadaan ini menyebabkan mikroorganisme yang terlibat dalam proses penguraian kekurangan hara nitrogen (Purnomo et al., 2017). Pupuk kandang yang memiliki nisbah $\mathrm{C} / \mathrm{N}$ yang tinggi menandakan lebih banyak mengandung $\mathrm{C}$ daripada $\mathrm{N}$ sehingga akan ada persaingan nitrogen antara tanaman dan mikroorganisme, mikroorganisme akan menggunakan nitrogen yang ada untuk pembentukan dan perkembangannya, nitrogen tersebut akan diikat pada tubuh mikroorganisme dan akan kurang tersedia di dalam tanah (Murtinah et al., 2020).

Peningkatan efektifitas serta mutu pupuk kandang dapat dilakukan dengan pemberian biofertilizer seperti Plant Growth Promoting Rhizobacteria (PGPR). Bakteri PGPR adalah mikroba tanah yang dapat meningkatkan pertumbuhan tanaman dan meningkatkan ketahanan tanaman terhadap serangan patogen tertentu. Prinsip pemberian PGPR adalah meningkatkan jumlah bakteri yang aktif di sekitar perakaran tanaman sehingga memberikan keuntungan bagi tanaman. Bakteri PGPR dapat diinokulasi dari berbagai akar tanaman seperti akar bambu, putri malu, rumput gajah, dan kacang-kacangan. Perlu dilakukan analisa jenis serta jumlah bakteri yang terdapat pada isolat PGPR yang digunakan sebelum diaplikasikan pada tanaman budidaya. Analisa bakteri digunakan sebagai parameter untuk mengetahui efektivitas serta potensi yang terkandung dalam bakteri tersebut. Bakteri PGPR akan hidup dan berkembang pada kondisi tanah tertentu. Faktor yang dapat memacu perkembangan PGPR diantaranya besarnya konsentrasi dan dosis penggunaan, kondisi tanah, formulasi perbanyakan, ketersediaan bahan organik dalam tanah, dan tanaman inang yang sesuai. Tanah dengan $\mathrm{pH}$ yang masam akan menjadi penghambat PGPR untuk hidup dan berkembang. Pada tanah dengan $\mathrm{pH}$ masam biasanya kandungan bahan organiknya akan jauh lebih sedikit.

Pemberian pupuk kandang dapat menyediakan nutrisi bagi PGPR, sehingga mikroorganisme dalam PGPR mampu bertahan hidup (Rohmawati et al., 2017). Manfaat bagi pupuk kandang, PGPR menjadi biofertilizer yang dapat mempercepat penguraian unsur hara yang terkandung dalam pupuk kandang. Pemberian PGPR $15 \mathrm{ml} / \mathrm{l}$ memiliki hasil tertinggi pada parameter tinggi tanaman dan luas daun buncis (Ningsih et al., 2018). Penggunaan PGPR dari akar bambu dengan konsentrasi6 $\mathrm{ml} / \mathrm{l}$ air dapat meningkatkan pertumbuhan tanaman dan bobot buah per tanaman pada tanaman cabai (Lisa et al., 2018). Penelitian ini bertujuan untuk mengkaji pemberian jenis pupuk kandang dengan konsentrasi PGPR yang berbeda terhadap petumbuhan dan produksi tanaman cabai.

\section{BAHAN DAN METODE}

Penelitian ini dilaksanakan di Greenhouse dan Laboratorium Ekologi dan Produksi Tanaman, Fakultas Peternakan dan Pertanian Universitas Diponegoro, Semarang pada Maret hingga Juli 2020. Lokasi penelitian secara geografis 
terletak pada ketinggian tempat 125 meter di atas permukaan laut dengan jenis tanah yaitu latosol dan $\mathrm{pH} 6,33$.

Alat yang digunakan dalam penelitian adalah kompor, panci, saringan, spatula, botol, gayung, corong, tray, cangkul, sekop, dirigen, gembor, selang, semprotan selang air, bambu, meteran, polybag, timbangan, spektrofotometer, oven, erlenmeyer, tabung reaksi, blok digestion, labu didih, amplop coklat, plastik, kamera, dan alat tulis. Bahan yang digunakan dalam penelitian adalah benih cabai keriting merah varietas Bisi HP 31, PGPR komersial, akar bambu, air, bekatul, terasi, gula pasir, kapur sirih, tanah, pupuk kandang ayam, pupuk kandang sapi, pupuk kandang kambing, bahan analisis nitrogen $(\mathrm{N})$, fosfor $(\mathrm{P})$, kalium (K), dan C-organik.

Penelitian dilakukan dengan menggunakan Rancangan Acak lengkap (RAL) pola faktorial $3 \times 5$ dengan 3 ulangan. Faktor pertama yaitu jenis pupuk kandang (P) setara dengan $200 \mathrm{~kg} \mathrm{~N} / \mathrm{ha}$ dan berdasarkan kebutuhan unsur hara tanaman cabai (Balitsa, 2007) terdiri dari pupuk kandang ayam (P1), pupuk kandang sapi (P2), dan pupuk kandang kambing (P3). Faktor kedua terdiri dari $0 \mathrm{ml} / \mathrm{l}$ (B0), PGPR komersial 5 g/l (B1), PGPR 5 ml/l (B2), PGPR 12,5 ml/l (B3) dan PGPR $20 \mathrm{ml} / \mathrm{l}$ (B4). Data yang diperoleh dianalisis menggunakan analisis ragam (ANOVA). Apabila hasil data signifikan maka dilakukan uji lanjut dengan metode Duncan Multiple Range Test (DMRT) pada taraf 5\%.

\section{HASIL DAN PEMBAHASAN}

\section{Hasil Pertumbuhan Tanaman}

Tabel 1. Tinggi Tanaman Cabai pada Perlakuan Jenis Pupuk Kandang dan Konsentrasi PGPR

\begin{tabular}{|c|c|c|c|c|c|c|}
\hline \multirow[b]{2}{*}{ Jenis Pukan } & \multicolumn{5}{|c|}{ Konsentrasi PGPR } & \multirow[b]{2}{*}{$\begin{array}{l}\text { Rata- } \\
\text { rata }\end{array}$} \\
\hline & $\begin{array}{c}\mathrm{B} 0 \\
(0 \mathrm{ml} / \mathrm{l})\end{array}$ & $\begin{array}{c}\text { B1 } \\
\text { (komersial } \\
5 \mathrm{~g} / \mathrm{l})\end{array}$ & $\begin{array}{c}\mathrm{B} 2 \\
(5 \mathrm{ml} / \mathrm{l})\end{array}$ & $\begin{array}{c}\mathrm{B} 3 \\
(12,5 \\
\mathrm{ml} / \mathrm{l})\end{array}$ & $\begin{array}{c}\mathrm{B} 4 \\
(20 \\
\mathrm{ml} / \mathrm{l})\end{array}$ & \\
\hline & \multicolumn{5}{|c|}{----------------------(cm)---------------------- } & \\
\hline $\begin{array}{l}\text { P1 (pukan } \\
\text { ayam) }\end{array}$ & 103,00 & 116,67 & 120,33 & 97,33 & 96,67 & $106,80^{\mathrm{a}}$ \\
\hline P2 (pukan sapi) & 97,33 & 81,67 & 87,67 & 112,00 & 76,67 & $91,07^{\mathrm{b}}$ \\
\hline $\begin{array}{l}\text { P3 (pukan } \\
\text { kambing) }\end{array}$ & 97,67 & 81,67 & 98,00 & 88,00 & 84,33 & $89,93^{\mathrm{b}}$ \\
\hline Rata-rata & 99,33 & 93,33 & 102,00 & 99,11 & 85,89 & \\
\hline
\end{tabular}

Superskip yang berbeda pada kolom yang sama menunjukkan berbeda nyata $(\mathrm{p}<0,05)$.

\section{Tinggi Tanaman}

Hasil uji jarak berganda Duncan terhadap jenis pupuk kandang dan konsentrasi PGPR pada parameter tinggi tanaman cabai disajikan pada Tabel 1. Berdasarkan uji lanjut yang dilakukan didapatkan hasil bahwa pemberian pupuk kandang berpengaruh nyata terhadap rata-rata tinggi tanaman cabai. Tinggi tanaman cabai dengan perlakuan pupuk kandang ayam memberikan hasil rata-rata tertinggi dan berbeda nyata dengan perlakuan pupuk kandang sapi dan pupuk 
kandang kambing. Hal ini dikarenakan besarnya rasio $\mathrm{C} / \mathrm{N}$ yang terdapat pada pupuk kandang ayam lebih rendah jika dibanding dengan rasio $\mathrm{C} / \mathrm{N}$ pada pupuk kandang sapi dan pupuk kandang kambing. Rasio $\mathrm{C} / \mathrm{N}$ yang rendah menunjukkan bahwa ketersediaan unsur hara dalam pupuk lebih tinggi dan lebih cepat tersedia serta dapat diserap oleh akar tanaman cabai.Nilai rasio $\mathrm{C} / \mathrm{N}$ dari pupuk kandang ayam merupakan yang paling mendekati dengan besarnya rasio $\mathrm{C} / \mathrm{N}$ yang menyamai rasio $\mathrm{C} / \mathrm{N}$ tanah yakni pada angka $10-12$ (Surtinah, 2012).

Tabel 2. Jumlah Daun Tanaman Cabai pada Perlakuan Jenis Pupuk Kandang dan Konsentrasi PGPR

\begin{tabular}{|c|c|c|c|c|c|c|}
\hline \multirow[b]{2}{*}{ Jenis Pukan } & \multicolumn{5}{|c|}{ Konsentrasi PGPR } & \multirow[b]{2}{*}{$\begin{array}{c}\text { Rata- } \\
\text { rata }\end{array}$} \\
\hline & $\begin{array}{c}\text { B0 } \\
(0 \mathrm{ml} / \mathrm{l})\end{array}$ & $\begin{array}{c}\mathrm{B} 1 \\
\text { (komersial } \\
5 \mathrm{~g} / \mathrm{l} \text { ) }\end{array}$ & $\begin{array}{c}\mathrm{B} 2 \\
(5 \mathrm{ml} / \mathrm{l})\end{array}$ & $\begin{array}{c}\text { B3 } \\
(12,5 \\
\mathrm{ml} / \mathrm{l})\end{array}$ & $\begin{array}{c}\mathrm{B} 4 \\
(20 \\
\mathrm{ml} / \mathrm{l})\end{array}$ & \\
\hline & \multicolumn{6}{|c|}{ |----------------------(helai)---------------------- } \\
\hline $\begin{array}{l}\text { P1 (pukan } \\
\text { ayam) }\end{array}$ & 104,33 & 227,33 & 237,00 & 126,67 & 114,33 & 161,93 \\
\hline P2 (pukan sapi) & 82,00 & 131,67 & 189,67 & 201,00 & 143,33 & 149,53 \\
\hline $\begin{array}{l}\text { P3 (pukan } \\
\text { kambing) }\end{array}$ & 186,67 & 129,00 & 126,33 & 87,67 & 91,33 & 124,20 \\
\hline Rata-rata & 124,33 & 162,67 & 184,33 & 138,44 & 116,33 & \\
\hline
\end{tabular}

Tabel 3. Umur Berbunga Tanaman Cabai pada Perlakuan Jenis Pupuk Kandang dan Konsentrasi PGPR

\begin{tabular}{|c|c|c|c|c|c|c|}
\hline \multirow[b]{2}{*}{ Jenis Pukan } & \multicolumn{5}{|c|}{ Konsentrasi PGPR } & \multirow[b]{2}{*}{$\begin{array}{c}\text { Rata- } \\
\text { rata }\end{array}$} \\
\hline & $\begin{array}{c}\mathrm{B} 0 \\
(0 \mathrm{ml} / \mathrm{l})\end{array}$ & $\begin{array}{c}\text { B1 } \\
\text { (komersial } \\
5 \mathrm{~g} / \mathrm{l})\end{array}$ & $\begin{array}{c}\mathrm{B} 2 \\
(5 \mathrm{ml} / \mathrm{l})\end{array}$ & $\begin{array}{c}\text { B3 } \\
(12,5 \\
\mathrm{ml} / \mathrm{l})\end{array}$ & $\begin{array}{c}\mathrm{B} 4 \\
(20 \\
\mathrm{ml} / \mathrm{l})\end{array}$ & \\
\hline & \multicolumn{5}{|c|}{----------------------(HST)---------------------- } & \\
\hline $\begin{array}{l}\text { P1 (pukan } \\
\text { ayam) }\end{array}$ & 37,67 & 35,67 & 34,33 & 35,33 & 38,33 & 36,27 \\
\hline P2 (pukan sapi) & 33,67 & 34,67 & 35,33 & 34,67 & 36,67 & 35,00 \\
\hline $\begin{array}{l}\text { P3 (pukan } \\
\text { kambing) }\end{array}$ & 36,33 & 36,33 & 37,00 & 34,33 & 34,00 & 35,60 \\
\hline Rata-rata & 35,89 & 35,56 & 35,56 & 34,78 & 36,33 & \\
\hline
\end{tabular}

Peningkatan konsentrasi PGPR dan interaksi antara perlakuan jenis pupuk kandang dan konsentrasi PGPR belum dapat memberikan hasil yang signifikan terhadap peningkatan tinggi tanaman cabai. Hal ini diduga karena dosis pengaplikasian PGPR kurang tepat dan kondisi media tanam kurang sesuai dengan syarat tumbuh PGPR. Dosis PGPR yang digunakan sebesar 200 $\mathrm{ml} /$ tanaman diduga kurang sesuai sehingga belum mampu meningkatkan pertumbuhan dan ketahanan tanaman terhadap hama yang menyerang tanaman cabai. Penggunaan dosis PGPR dalam satu kali aplikasi pada tanaman cabai yaitu $250 \mathrm{ml} /$ tanaman (Fajrin dan Santoso, 2019). Pengaplikasian PGPR di lapangan perlu memerhatikan beberapa faktor lingkungan, diantaranya adalah kondisi 
tanah, iklim, dan vegetasi. Selain itu, perlu dilakukan analisa awal isolat bakteri yang digunakan sebelum diaplikasikan pada tanaman. Menurut Widawati (2015) bahwa analisa jenis serta jumlah bakteri yang terdapat pada kelompok Plant Growth Promoting Rhizobacteria (PGPR) merupakan parameter untuk mengetahui efektivitas bakteri tersebut sebagai pupuk organik hayati.

\section{Jumlah Daun}

Hasil uji jarak berganda Duncan terhadap perlakuan jenis pupuk kandang dan konsentrasi PGPR pada parameter rata-rata jumlah daun tanaman cabai disajikan pada Tabel 2. Pemberian jenis pupuk kandang yang berbeda, konsentrasi PGPR, serta interaksi jenis pupuk kandang dan konsentrasi PGPR tidak memberikan pengaruh nyata terhadap rata-rata jumlah daun tanaman cabai. Adanya serangan hama thrips, kutu kebul, dan tungau juga menjadi salah satu penyebab daun tanaman menjadi tidak normal. Daun yang terserang hama menjadi melengkung ke bawah, kaku, keriting, dan rontok. Hal tersebut diduga menjadi penyebab pemberian perlakuan terhadap rata-rata jumlah daun tidak didapatkan hasil yang signifikan. Sesuai pendapat Sugiyono et al. (2014) bahwa gejala nimfa thrips dicirikan dengan daun-daun yang mengerut hingga rontok dan tanaman menjadi kerdil.

Peningkatan konsentrasi PGPR belum mampu meningkatkan pertumbuhan jumlah daun pada tanaman cabai. Perlu ketelitian dalam setiap pelaksanaan metode penelitian. Tidak dilakukan analisa awal kandungan isolat bakteri PGPR yang digunakan sehingga kualitas kandungan bakteri serta jumlah bakteri di dalamnya tidak dapat diketahui. Sebelum bakteri dijadikan formula dan diaplikasikan pada tanaman budidaya, terlebih dahulu perlu dilakukan analisa terhadap potensinyadiantaranya mampu meproduksi hormon tumbuh (IAA), bakteri penambat nitrogen, serta bakteri pelarut fosfat (Utami et al., 2018).

\section{Umur Berbunga}

Umur berbunga merupakan perhitungan hari sejak pindah tanam hingga bunga jantan dan bunga betina mekar untuk pertama kali. Pemberian jenis pupuk kandang yang berbeda tidak berpengaruh terhadap rata-rata umur berbunga tanaman cabai. Pupuk kandang memiliki sifat yang lama tersedia bagi tanaman meskipun kandungan unsur hara didalamnya lebih bervariasi. Hal tersebut membuat pada saat awal pertumbuhan tanaman hasil dari pemberian jenis pupuk kandang yang berbeda belum terlihat signifikan. Rata-rata umur berbunga yang muncul pertama yaitu pada minggu ke 4 dan minggu ke 5. Hal ini sesuai dengan deskripsi cabai merah varietas yang digunakan yaitu BISI HP 31 dalam Kementan RI (2015) yang memiliki umur berbunga yaitu 32 - 39 HST. Kecepatan berbunga suatu tanaman lebih dipengaruhi oleh 3 faktor yaitu fotoperiodisme, fitokrom, dan ritme biologi pada tanaman itu sendiri (Suyoto, 2011).

Peningkatan konsentrasi PGPR dan interaksi jenis pupuk kandang dan konsentrasi PGPR juga tidak berpengaruh nyata terhadap umur berbunga. Hasil pengaplikasian PGPR tidak efektif bahkan sama dengan hasil pada tanaman tanpa pengaplikasian PGPR. Kurangnya ketelitian dalam penggunaan PGPR mengakibatkan PGPR tidak bekerja secara optimal dan tidak berpengaruh pada 
pertumbuhan tanaman. Tidak dilakukannya analisa kualitas PGPR sehingga tidak diketahui potensi bakteri yang terkandung. Analisa bakteri dilakukan untuk mengetahui adanya bakteri pelarut fosfat, bakteri penambat nitrogen, dan perombak bahan organik. Teknik pengaplikasian PGPR serta kondisi media tanam juga perlu diperhatikan. Hasil yang didapat dari pengaplikasian PGPR akan lebih optimal terlihat apabila kondisi tanah berada pada tingkat kemasaman $(\mathrm{pH})$ netral karena tanah dengan $\mathrm{pH}$ masam akan menjadi pembatas bagi keberlangsungan hidup dan perkembangan PGPR. Bahan organik mempengaruhi besar kecilnya daya serap tanah akan air. Semakin banyak air dalam tanah maka semakin banyak reaksi pelepasan ion $\mathrm{H}+$ sehingga tanah menjadi masam (Prabowo, 2018)

\section{Hasil Produksi Tanaman}

Tabel 4. Bobot BuahTanaman Cabai pada Perlakuan Jenis Pupuk Kandang dan Konsentrasi PGPR

\begin{tabular}{|c|c|c|c|c|c|c|}
\hline \multirow[b]{2}{*}{ Jenis Pukan } & \multicolumn{5}{|c|}{ Konsentrasi PGPR } & \multirow[b]{2}{*}{$\begin{array}{c}\text { Rata- } \\
\text { rata }\end{array}$} \\
\hline & $\begin{array}{c}\mathrm{B} 0 \\
(0 \mathrm{ml} / \mathrm{l})\end{array}$ & $\begin{array}{c}\mathrm{B} 1 \\
\text { (komersial } \\
5 \mathrm{~g} / \mathrm{l})\end{array}$ & $\begin{array}{c}\mathrm{B} 2 \\
(5 \mathrm{ml} / \mathrm{l})\end{array}$ & $\begin{array}{c}\text { B3 } \\
(12,5 \\
\mathrm{ml} / \mathrm{l}) \\
\end{array}$ & $\begin{array}{c}\mathrm{B} 4 \\
(20 \\
\mathrm{ml} / \mathrm{l}) \\
\end{array}$ & \\
\hline \multicolumn{7}{|c|}{----------------------(g)--------------------- } \\
\hline $\begin{array}{l}\text { P1 (pukan } \\
\text { ayam) }\end{array}$ & 20,67 & 32,23 & 26,97 & 24,33 & 18,80 & $24,60^{\mathrm{a}}$ \\
\hline P2 (pukan sapi) & 23,13 & 19,23 & 18,60 & 25,83 & 14,17 & $20,19^{\mathrm{ab}}$ \\
\hline $\begin{array}{l}\text { P3 (pukan } \\
\text { kambing) }\end{array}$ & 12,63 & 18,07 & 15,97 & 8,80 & 10,73 & $13,24^{\mathrm{b}}$ \\
\hline Rata-rata & 18,81 & 23.18 & 20,51 & 19,65 & 14,56 & \\
\hline
\end{tabular}

Superskip yang berbeda pada kolom yang sama menunjukkan berbeda nyata $(\mathrm{p}<0,05)$

Tabel 5. Jumlah BuahTanaman Cabai pada Perlakuan Jenis Pupuk Kandang dan Konsentrasi PGPR

\begin{tabular}{|c|c|c|c|c|c|c|}
\hline \multirow[b]{2}{*}{ Jenis Pukan } & \multicolumn{5}{|c|}{ Konsentrasi PGPR } & \multirow[b]{2}{*}{$\begin{array}{c}\text { Rata- } \\
\text { rata }\end{array}$} \\
\hline & $\begin{array}{c}\mathrm{B} 0 \\
(0 \mathrm{ml} / \mathrm{l})\end{array}$ & $\begin{array}{c}\mathrm{B} 1 \\
\text { (komersial } \\
5 \mathrm{~g} / \mathrm{l}) \\
\end{array}$ & $\begin{array}{c}\mathrm{B} 2 \\
(5 \mathrm{ml} / \mathrm{l})\end{array}$ & $\begin{array}{c}\text { B3 } \\
(12,5 \\
\mathrm{ml} / \mathrm{l}) \\
\end{array}$ & $\begin{array}{c}\mathrm{B} 4 \\
(20 \\
\mathrm{ml} / \mathrm{l}) \\
\end{array}$ & \\
\hline \multicolumn{7}{|c|}{--------------------'(Buah)-------------------- } \\
\hline $\begin{array}{l}\mathrm{P} 1 \quad \text { (pukan } \\
\text { ayam) }\end{array}$ & 5,33 & 8,33 & 9,33 & 8,00 & 5,33 & $7,26^{\mathrm{a}}$ \\
\hline P2 (pukan sapi) & 7,00 & 5,33 & 4,67 & 6,33 & 4,00 & $5,47^{\mathrm{ab}}$ \\
\hline $\begin{array}{l}\text { P3 (pukan } \\
\text { kambing) }\end{array}$ & 8,33 & 6,00 & 4,00 & 2,33 & 3,33 & $4,80^{\mathrm{b}}$ \\
\hline Rata-rata & 6,89 & 6,55 & 6,00 & 5,55 & 4,22 & \\
\hline
\end{tabular}

Superskip yang berbeda pada kolom yang sama menunjukkan berbeda nyata $(\mathrm{p}<0,05)$ 
Tabel 6. Berat Segar Tanaman Cabai pada Perlakuan Jenis Pupuk Kandang dan Konsentrasi PGPR

\begin{tabular}{|c|c|c|c|c|c|c|}
\hline \multirow[b]{2}{*}{ Jenis Pukan } & \multicolumn{5}{|c|}{ Konsentrasi PGPR } & \multirow[b]{2}{*}{$\begin{array}{c}\text { Rata- } \\
\text { rata }\end{array}$} \\
\hline & $\begin{array}{c}\mathrm{B} 0 \\
(0 \mathrm{ml} / \mathrm{l})\end{array}$ & $\begin{array}{c}\mathrm{B} 1 \\
\text { (komersial } \\
5 \mathrm{~g} / \mathrm{l})\end{array}$ & $\begin{array}{c}\mathrm{B} 2 \\
(5 \mathrm{ml} / \mathrm{l})\end{array}$ & $\begin{array}{c}\text { B3 } \\
(12,5 \\
\mathrm{ml} / \mathrm{l}) \\
\end{array}$ & $\begin{array}{c}\mathrm{B} 4 \\
(20 \\
\mathrm{ml} / \mathrm{l}) \\
\end{array}$ & \\
\hline & \multicolumn{5}{|c|}{---------------------(g)--------------------- } & \\
\hline $\begin{array}{l}\text { P1 (pukan } \\
\text { ayam) }\end{array}$ & 75,29 & 111,41 & 110,22 & 72,42 & 93,18 & $92,50^{\mathrm{a}}$ \\
\hline P2 (pukan sapi) & 79,08 & 84,69 & 72,68 & 94,38 & 86,40 & $83,45^{\mathrm{ab}}$ \\
\hline $\begin{array}{l}\text { P3 (pukan } \\
\text { kambing) }\end{array}$ & 77,06 & 70,97 & 78,56 & 66,17 & 57,42 & $70,03^{\mathrm{b}}$ \\
\hline Rata-rata & 77,14 & 89,02 & 87,15 & 77,66 & 79,00 & \\
\hline
\end{tabular}

Superskip yang berbeda pada kolom yang sama menunjukkan berbeda nyata $(\mathrm{p}<0,05)$

Tabel 7. Produksi Bahan Kering TajukTanaman Cabai pada Perlakuan Jenis Pupuk Kandang dan Konsentrasi PGPR

\begin{tabular}{|c|c|c|c|c|c|c|}
\hline \multirow[b]{2}{*}{ Jenis Pukan } & \multicolumn{5}{|c|}{ Konsentrasi PGPR } & \multirow[b]{2}{*}{$\begin{array}{c}\text { Rata- } \\
\text { rata }\end{array}$} \\
\hline & $\begin{array}{c}\mathrm{B} 0 \\
(0 \mathrm{ml} / \mathrm{l})\end{array}$ & $\begin{array}{c}\mathrm{B} 1 \\
\text { (komersial } \\
5 \mathrm{~g} / \mathrm{l})\end{array}$ & $\begin{array}{c}\mathrm{B} 2 \\
(5 \mathrm{ml} / \mathrm{l})\end{array}$ & $\begin{array}{c}\mathrm{B} 3 \\
(12,5 \\
\mathrm{ml} / \mathrm{l}) \\
\end{array}$ & $\begin{array}{c}\mathrm{B} 4 \\
(20 \\
\mathrm{ml} / \mathrm{l}) \\
\end{array}$ & \\
\hline & \multicolumn{5}{|c|}{---------------------(\%)--------------------- } & \\
\hline $\begin{array}{l}\text { P1 (pukan } \\
\text { ayam) }\end{array}$ & 11,33 & 19,26 & 20,11 & 13,08 & 17,23 & $16,20^{\mathrm{a}}$ \\
\hline P2 (pukan sapi) & 12,59 & 15,13 & 13,17 & 14,81 & 15,00 & $14,14^{\mathrm{ab}}$ \\
\hline $\begin{array}{l}\text { P3 (pukan } \\
\text { kambing) }\end{array}$ & 14,55 & 12,89 & 13,09 & 10,38 & 9,24 & $12,03^{b}$ \\
\hline Rata-rata & 12,82 & 15,76 & 15,46 & 12,76 & 13,82 & \\
\hline
\end{tabular}

Superskip yang berbeda pada kolom yang sama menunjukkan berbeda nyata $(\mathrm{p}<0,05)$

\section{Bobot Buah Per Tanaman}

Hasil uji lanjut terhadap perlakuan jenis pupuk kandang dan konsentrasi PGPR pada parameter rata-rata bobot buah per tanaman disajikan pada Tabel 4 . Berdasarkan hasil didapat diketahui bahwa pemberian pupuk kandang berpengaruh nyata terhadap bobot buah per tanaman. Hasil pupuk kandang ayam tidak berbeda nyata dengan hasil pupuk kandang sapi tetapi berbeda nyata dengan hasil pemberian pupuk kandang kambing. Sedangkan pemberian pupuk kandang sapi didapatkan hasil tidak berbeda nyata dengan pemberian pupuk kandang kambing.

Pembentukan buah sangat dipengaruhi oleh unsur hara yang akan digunakan dalam proses fotosintesis. Unsur hara makro (N, P, dan $\mathrm{K}$ ) merupakan penyusun karbohidrat, lemak, protein, mineral, dan vitamin yang akan ditranslokasikan ke bagian penyimpanan buah. Unsur $\mathrm{P}$ adalah unsur penting kedua setelah nitrogen 
yang memiliki peran dalam proses fotosintesis, perkembangan akar, pembentukan bunga, buah, dan biji (Bachtiar et al., 2016). Pemberian pupuk kandang ayam memberikan suplai hara makro lebih tinggi dibanding dengan dua pupuk lainnya. Rasio $\mathrm{C} / \mathrm{N}$ pupuk kandang ayam lebih rendah sehingga unsur hara yang terkandung dalam pupuk kandang ayam lebih cepat diserap oleh akar tanaman. Tingginya $\mathrm{C} / \mathrm{N}$ rasio pupuk kandang menyebabkan proses penguraian hara berjalan lambat dan kurang tersedia bagi tanaman sehingga menghambat penggunaan langsung karena akan menekan pertumbuhan tanaman.

Tabel 8. Produksi Bahan Kering Akar Tanaman Cabai pada Perlakuan Jenis Pupuk Kandang dan Konsentrasi PGPR

\begin{tabular}{|c|c|c|c|c|c|c|}
\hline \multirow[b]{2}{*}{ Jenis Pukan } & \multicolumn{5}{|c|}{ Konsentrasi PGPR } & \multirow[b]{2}{*}{$\begin{array}{l}\text { Rata- } \\
\text { rata }\end{array}$} \\
\hline & $\begin{array}{c}\mathrm{B} 0 \\
(0 \mathrm{ml} / \mathrm{l})\end{array}$ & $\begin{array}{c}\text { B1 } \\
\text { (komersial } \\
5 \mathrm{~g} / \mathrm{l})\end{array}$ & $\begin{array}{c}\mathrm{B} 2 \\
(5 \mathrm{ml} / \mathrm{l})\end{array}$ & $\begin{array}{c}\text { B3 } \\
(12,5 \\
\mathrm{ml} / \mathrm{l}) \\
\end{array}$ & $\begin{array}{c}\mathrm{B} 4 \\
(20 \\
\mathrm{ml} / \mathrm{l}) \\
\end{array}$ & \\
\hline & \multicolumn{5}{|c|}{----------------------(\%) } & \\
\hline $\begin{array}{l}\text { P1 (pukan } \\
\text { ayam) }\end{array}$ & 1,82 & 1,70 & 1,37 & 3,39 & 1,12 & $1,88^{\mathrm{a}}$ \\
\hline P2 (pukan sapi) & 1,73 & 1,71 & 1,29 & 1,53 & 1,55 & $1,56^{\mathrm{ab}}$ \\
\hline $\begin{array}{l}\text { P3 (pukan } \\
\text { kambing) }\end{array}$ & 0,94 & 1,25 & 0,99 & 0,84 & 0,88 & $0,98^{b}$ \\
\hline Rata-rata & 1,50 & 1,55 & 1,22 & 1,92 & 1,18 & \\
\hline
\end{tabular}

Superskip yang berbeda pada kolom yang sama menunjukkan berbeda nyata $(\mathrm{p}<0,05)$

Bakteri PGPR akan berkembang pada kondisi tanah tertentu. Faktor yang dapat memacu perkembangan populasi bakteri adalah kondisi $\mathrm{pH}$ tanah, ketersediaan bahan organik sebagai sumber nutrisi bakteri, dan tanaman inang yang sesuai. Tingkat kemasaman tanah merupakan faktor penting yang perlu diperhatikan agar aplikasi PGPR mendapatkan hasil yang optimal. Tanah dengan $\mathrm{pH}$ yang masam akan menjadi penghambat hidup poulasi PGPR sehingga mikroba tidak bekerja dengan baik dan bahkan bisa mati. Tanaman cabai terserang hama trips dan lalat buah dalam skala besar yang mengakibatkan aplikasi konsentrasi PGPR tidak didapatkan hasil yang signifikan. Serangan hama tersebut mengakibatkan terjadinya penurunan produksi buah cabai. Kondisi lingkungan yang kurang sesuai akan mempersulit pengendalian hama yang terjadi. Suhu lingkungan yang terlalu tinggi menyebabkan serangan hama semakin tinggi dan sulit dikendalikan sehingga produksi tanaman lebih rendah. Norenza et al. (2019) menyatakan bahwa kenaikan serangan hama diduga karena pengaruh kenaikan suhu hingga pada suhu optimum untuk perkembangan hama.

\section{Jumlah Buah Per Tanaman}

Hasil uji jarak berganda Duncan terhadap perlakuan jenis pupuk kandang dan konsentrasi PGPR pada parameter rata-rata bobot jumlah per tanaman disajikan pada Tabel 5. Berdasarkan hasil dari uji jarak berganda Duncan diketahui bahwa pemberian pupuk kandang berpengaruh nyata terhadap jumlah 
buah per tananam pada tanaman cabai.Hasil pupuk kandang ayam tidak berbeda nyata dengan hasil pupuk kandang sapi tetapi berbeda nyata dengan pupuk kandang kambing. Namun perlakuan pupuk kandang sapi tidak berbeda nyata dengan pemberian pupuk kandang kambing.

Besarnya Rasio $\mathrm{C} / \mathrm{N}$ berpengaruh pada ketersediaan unsur hara bagi tanaman. Nilai dari rasio $\mathrm{C} / \mathrm{N}$ berbanding terbalik dengan ketersediaan unsur hara yang dapat diserap akar tanaman. Rasio $\mathrm{C} / \mathrm{N}$ pupuk yang terlalu tinggi menyebabkan proses penguraian unsur hara berlangsung lebih lambat yang dikarenakan mikroorganisme kekurangan nitrogen. Hasil pupuk kandang ayam tidak berbeda nyata dengan hasil pupuk kandang sapi tetapi berbeda nyata dengan hasil pemberian pupuk kandang kambing. Sedangkan pemberian pupuk kandang sapi didapatkan hasil tidak berbeda nyata dengan pemberian pupuk kandang kambing. Pupuk kandang ayam dan pupuk kandang sapi yang digunakan dalam penelitian memiliki nilai rasio $\mathrm{C} / \mathrm{N}$ yang lebih rendah dan lebih mendekati nilai rasio $\mathrm{C} / \mathrm{N}$ tanah dibanding dengan pupuk kandang kambing. Menurut Sitompul et al. (2017) bahwa bahan organik yang mempunyai kandungan rasio $\mathrm{C} / \mathrm{N}$ mendekati atau sama dengan rasio $\mathrm{C} / \mathrm{N}$ tanah yaitu 10-20 maka bahan tersebut dapat digunakan atau lebih cepat diserap tanaman.

Peran PGPR pada pertumbuhan tanaman cabai tidak efektif bahkan hasil pada parameter jumlah buah lebih rendah dibanding dengan tanpa pengaplikasian PGPR.Kerja PGPR dipengaruhi oleh jenis bakteri serta kondisi lingkungan tempat PGPR tumbuh. Perlu dilakukan analisa awal pada isolat PGPR sebelum diaplikasikan pada tanaman untuk mengetahui bakteri hidup yang terdapat dalam PGPR. Kondisi lingkungan rizosfer harus sesuai dan mampu menyediakan nutrisi bagi pertumbuhan PGPR sehingga PGPR dapat menjalankan perannya dengan baik bagi tanah maupun tanaman. PGPR akan bekerja secara optimal perlu didukung dengan adanya nutrisi yang didapat dari bahan organik (Shofiah dan Tyasmoro, 2018).

\section{Berat Segar Tanaman}

Hasil uji jarak berganda Duncan terhadap perlakuan jenis pupuk kandang dan konsentrasi PGPR pada parameter rata-rata berat segar tanaman cabai disajikan pada Tabel 6. Berdasarkan hasil dari uji jarak berganda Duncan diketahui bahwa pemberian pupuk kandang berpengaruh nyata terhadap berat segar tananam cabai. Hasil pupuk kandang ayam tidak berbeda nyata dengan hasil pupuk kandang sapi tetapi berbeda nyata dengan hasil pemberian pupuk kandang kambing. Sedangkan pemberian pupuk kandang sapi didapatkan hasil tidak berbeda nyata dengan pemberian pupuk kandang kambing.

Biomassa tanaman merupakan parameter yang sering digunakan untuk menggambarkan pertumbuhan dan perkembangan tanaman. Pertumbuhan dan perkembangan tanaman akan meningkat seiring dengan tersedianya unsur hara di tanah yang dapat diserap oleh akar tanaman yang kemudian ditranslokasikan ke daun untuk proses fotosintesis. Tersedianya unsur hara yang dapat diserap oleh tanaman dipengaruhi oleh cepat atau lambatnya proses dekomposisi bahan-bahan organik. Prasetyo (2014) menyatakan bahwa kecepatan penyerapan unsur hara oleh tanaman dipengaruhi oleh kecepatan proses dekomposisi. 
Pemberian perlakuan PGPR pada konsentrasi yang berbeda serta interaksi perlakuan jenis pupuk kandang dan konsentrasi PGPR tidak menunjukkan adanya pengaruh nyata terhadap berat segar tanaman cabai. Apabila tinggi tanaman serta jumlah daun menunjukkan hasil yang berbeda nyata, maka diikuti dengan berat segar tanaman, begitu pun sebaliknya. Hal ini sesuai dengan pendapat Pramitasari et al. (2016) bahwa adanya pengaruh pemberian perlakuan terhadap berat segar dan berat konsumsi per tanaman berkaitan dengan hasil pada ukuran daun, jumlah daun, serta tinggi tanaman.

\section{Produksi Bahan Kering Tajuk}

Hasil uji jarak berganda Duncan terhadap perlakuan jenis pupuk kandang dan konsentrasi PGPR pada parameter produksi bahan kering tajuk tanaman cabai disajikan pada Tabel 7. Hasil analisis menunjukkan bahwa perlakuan jenis pupuk kandang berpengaruh terhadap produksi bahan kering tajuk tanaman cabai. Tanaman cabai dengan perlakuan pupuk kandang ayam (P1) memberikan hasil tertinggi, namun tidak berbeda nyata dengan perlakuan pupuk kandang sapi (P2). Perlakuan pupuk kandang ayam (P1) berbeda nyata dengan perlakuan pupuk kandang kambing (P3). Sedangkan perlakuan pupuk kandang sapi (P2) tidak berbeda dengan pupuk kandang kambing (P3).Perlakuan konsentrasi PGPR dan interaksi antara perlakuan jenis pupuk kandang dengan konsentrasi PGPR tidak berpengaruh terhadap produksi bahan kering tajuk tanaman cabai.

Tajuk merupakan keseluruhan bagian tanaman. Bahan kering dapat dijadikan acuan untuk menyatakan laju pertumbuhan vegetatif tanaman. Besarnya energi yang diserap tanaman menjadi fotosintat ditunjukkan dengan bahan kering yang terkandung dalam tanaman tersebut. Nilai bahan kering tajuk berkaitan dengan pertumbuhan vegetatif tanaman. Unsur hara makro misalnya fosfor dan nitrogen diperlukan untuk peningkatan bahan kering tajuk tanaman (Ghaisani et al., 2020). Besarnya nilai bahan kering tajuk bergantung dari banyaknya unsur hara yang dapat diserap tanaman selama masa pertumbuhan vegetatif. Saat tanaman sudah memasuki fase generatif, akumulasi bahan kering akan lebih banyak ditranslokasikan pada organ generatif tanaman daripada organ vegetatifnya. Menurut Alsabah et al. (2015) yang menyatakan bahwa akar dan tajuk tanaman memiliki fungsi sebagai penyalur hasil fotosintesis, sedangkan hasilnya yaitu buah dan biji, semakin tua umur tanaman maka akumulasi bahan kering akan lebih banyak dialokasi pada bagian generatif tanaman sementara akumulasi bahan kering pada bagian vegetatif seperti batang dan daun tidak banyak mengalami perubahan jumlah.

\section{Produksi Bahan Kering Akar}

Hasil uji jarak berganda Duncan terhadap perlakuan jenis pupuk kandang dan konsentrasi PGPR pada parameter produksi bahan kering akar tanaman cabai disajikan pada Tabel 8. Pemberian jenis pupuk kandang yang berbeda berpengaruh terhadap produksi bahan kering akar tanaman cabai. Konsentrasi PGPR serta interaksi jenis pupuk kandang dan konsentrasi PGPR tidak berpengaruh terhadap produksi bahan kering akar tanaman cabai. 
Produksi bahan kering tanaman dengan perlakuan pupuk kandang ayam (P1) memberikan hasil tertinggi yaitu 1,88 g/tanaman dan berbeda nyata dengan perlakuan pupuk kandang kambing (P3) 1,56 g/tanaman, akan tetapi tidak berbeda dengan perlakuan pupuk kandang sapi (P2) dengan 0,98 g/tanaman. Sedangkan pupuk kandang sapi (P2) hasilnya tidak berbeda nyata dengan pupuk kandang kambing (P3). Semakin tinggi fotosintat menunjukkan bahwa semakin banyak bahan kering yang disimpan oleh tanaman.Tersedianya unsur hara $\mathrm{N}, \mathrm{P}$ dan $\mathrm{K}$ pada setiap pupuk kandang memberikan pengaruh yang berbeda terhadap pertumbuhan tanaman cabai. Pupuk kandang ayam memiliki rasio $\mathrm{C} / \mathrm{N}$ yang lebih rendah sehingga unsur haranya lebih cepat tersedia. Risal dan Halim (2020) menyatakan bahwa dengan tersedianya unsur hara bagi tanaman, maka serapan unsur hara oleh tanaman akan meningkat dan berpengaruh terhadap pertumbuhan serta produksi tanaman.

PGPR merupakan bakteri yang aktif mengkolonisasi perakaran tanaman. Sesuai pendapat Raka et al. (2012) bahwa PGPR merupakan kelompok bakteri heterogen yang aktif mengkoloni akar tanaman dan dapat meningkatkan kesuburan tanah serta pertumbuhan dan hasil produksi tanaman. Kondisi lingkungan perakaran, kualitas PGPR, teknik aplikasi, serta dosis penggunaan yang tepat mempengaruhi kerja PGPR pada lingkungan rizosfer. PGPR tidak dapat bertahan dan tidak menjalankan perannya dengan optimal apabila kondisi tanah tidak sesuai.Menurut Ollo et al. (2019) bahwa kombinasi PGPR dan pupuk lain dapat bekerja dengan baik apabila nutrisi PGPR terpenuhi, PGPR juga memerlukan nutrisi untuk pertumbuhannya yang berasal dari pupuk lain.

\section{KESIMPULAN}

Berdasarkan hasil penelitian, dapat disimpulkan bahwa pemberian jenis pupuk kandang ayam memberikan pertumbuhan dan produksi cabai varietas HP 31 yang lebih tinggi dibandingkan dengan pupuk kandang sapi dan pupuk kandang kambing. Peningkatan konsentrasi PGPR maupun interaksi antara jenis pupuk kandang dan konsentrasi PGPR yang digunakan tidak berpengaruh pada seluruh variabel pengamatan yang diamati.

\section{DAFTAR PUSTAKA}

Alsabah, R., Sunyoto, F. Hidayat, dan M. Kamal. 2014. Akumulasi Bahan Kering Beberapa Varietas Jagung Hibrida (Zea mays L.) yang Ditumpangsarikan dengan Ubi Kayu (Manihot esculenta Crantz). J. Agrotek Tropika. 2 (3) : $394-399$.

Bachtiar, M. Ghulamahdi, M. Melati, D. Guntoro, dan A. Sutandi. 2016. Kecukupan Hara Fosfor Pada Pertumbuhan dan Produksi Kedelai Dengan Budidaya Jenuh Air Di Tanah Mineral Dan Bergambut. J. Ilmu tanah dan Lingkungan. 18 (1) : $21-27$.

Balitsa. 2007. Budidaya Tanaman Sayuran. Bandung. Jawa Barat. 
BPS. 2020. Statistik Hortikultura 2019. Jakarta.

Fajrin, M. dan M. Santoso. 2019. Pengaruh Media Tanam dan Pengaplikasian PGPR (plant growth promoting rhizobacteria) Terhadap Pertumbuhan dan Hasil Tanaman Okra (Abelmoschus esculentus L.) J. Produksi Tanaman. 7 (4) :681-689.

Ghaisani, A. R., D. R. Lukiwati, dan I. Mansur. 2020. Respon Pertumbuhan dan Hasil Cabai Rawit (Capsicum frustescens 1.) Akibat Inokulasi Cendawan Mikoriza Arbuskular Dan Pemupukan Fosfat. J. Agro Complex. 4 (1):1 - 7.

Kementan RI. 2015. Deskripsi Cabai Keriting Varietas Bisi HP 31. Jakarta.

Lisa, B. R. Widiati, dan Muhanniah. 2018. Serapan Unsur Hara Fosfor (P) Tanaman Cabai Rawit (Capsicum frustescens L.) pada Aplikasi PGPR (plant growth promoting rhizobacter) dan Trichokompos. J. Agrotan. 4 (1) : $57-73$.

Murtinah, E. Fuskhah, A. Darmawati. 2020. Pertumbuhan dan Produksi Kedelai Hitam (Glycine $\max$ L. Merill) pada Berbagai Jenis Pupuk Kandang Dan Konsentrasi Plant Growth Promothing Rhizobacteria. E-J. Undip. 5 (1) : 52 -59 .

Ningsih, Y. F., D. Armita, dan M. DS. Maghfoer. 2018. Pengaruh Konsentrasi dan Interval Pemberian PGPR Terhadap Pertumbuhan dan Hasil Buncis Tegak (Phaseolus vulgaris L.). J. Produksi Tanaman. 6 (7) : 1603 - 1612.

Norenza, E., T. Lestari, dan R. Apriyadi. 2019 Penetapan Dosis Tepung Daun Cengkeh Untuk Mengendalikan Hama Gudang Kacang Hijau (Callosobruchus Maculatus Fabricius.) Pada Suhu Penyimpanan Yang Berbeda. J. Agrosaintek. 3 (1) : $1-8$.

Ollo, L., P. Siahaan, dan B. Kolondam. 2019. Uji Penggunaan PGPR (Plant Growth Promoting Rhizobacteria) Terhadap Pertumbuhan Vegetatif Tanaman Cabai Merah (Capsicum annuum L.) J. Mipa Unsrat. 8 (3) : 150 155.

Prabowo, Rossi dan Subantoro R. 2018. Analisis Tanah Sebagai Indikator Tingkat Kesuburan Lahan Budidaya Pertanian di Kota Semarang. J. Cendekia Eksakta 2 (2): 59 - 64.

Pramitasari, H. E., T. Wardiyati, dan M. Nawawi. 2016. Pengaruh Dosis Pupuk Nitrogen Dan Tingkat Kepadatan Tanaman Terhadap Pertumbuhan Dan Hasil Tanaman Kailan (Brassica oleraceae L.). J. Produksi Tanaman. 4 (1) : $49-56$. 
Prasetyo, N. Dan M. Kusberyunadi. 2015. Respon Beberapa Varietas Cabai Merah (Capsicum annum L.) pada Berbagai Jenis Pupuk Kandang. J. Universitas PGRI Yogyakarta.

Purnomo, E. A., E. Sutrisno, dan S. Sumiyati. 2017. Pengaruh Variasi C/N Rasio Terhadap Produksi Kompos Dan Kandungan Kalium (K), Pospat (P) dari Batang Pisang Dengan Kombinasi Kotoran Sapi Dalam Sistem Vermicomposting. J. Teknik Lingkungan. 6 (2) : $1-15$.

Raka, I. G. N., K. Khalimi, I. D. N. Nyana, dan I. K. Saidi. 2012. Aplikasi Rhizobakteri Pantogea agglomerans untuk Meningkatkan Pertumbuhan Dan Hasil Tanaman Jagung (Zea mays, L.) Varietas Hibrida BISI-2. J. Agrotop. 2 (1) : $1-9$.

Risal, D. dan A. Halim. 2020. Uji Pupuk Organik Untuk Pertumbuhan Cabai Keriting Pada Tanah Miskin Hara. J. Ecosolum. 9 (1) : 19 - 27.

Rohmawati, F. A., R. Soelistyono, Koesriharti. 2017. Pengaruh Pemberian PGPR (Plant Growth Promoting Rhizobacteria) dan Kompos Kotoran Kelinci Terhadap Hasil Tanaman Terung (Solanum malongena L.). J. Produksi Tanaman. 5 (8) : $1294-1300$.

Shofiah, D. R. Dan S. Y. Tyasmoro. 2018. Aplikasi PGPR (Plant Growth Promoting Rhizobacteria) dan Pupuk Kotoran Kambing Pada Pertumbuhan Dan Hasil Bawang Merah (Allium ascalonicum L.) Varietas Manjung. J. Produksi Tanaman. $6(1): 76-82$.

Sitompul, E., I. W. Wardhana, dan E. Sutrisno. 2017. Studi Identifikasi Rasio C/N Pengolahan Sampah Organik Sayuran Sawi, Daun Singkong, dan Kotoran Kambing Dengan Variasi Komposisi Menggunakan Metode Vermikomposting. J. Teknik Lingkungan. 6 (2):1 - 12.

Sugiyono, B. R., G. Mudjioo, dan R. Rachmawati. 2014. Studi Kelimpahan Populasi Thrips sp. pada Perlakuan Pengelolaan Hama Terpadu Dan Konvensional Pada Tanaman Cabai (Capsicum annuum L.) di Desa Bayem Kecamatan Kasembon Kabupaten Malang. J. Hama Penyakit Tanaman. 2 (2) : $67-78$.

Surtinah. 2013. Pengujian Kandungan Unsur Hara Dalam Kompos Yang Berasal Dari Serasah Tanaman Jagung Manis (Zea mays Saccharata). J. Ilmiah Pertanian. 11(1) : $11-17$.

Suyoto. 2011. Fotoperiode dan Pembungaan Tanaman. Jurnal Buana Sain. 11 (2) : $137-144$. 
Utami, A. P. D. Agustiyani, dan E. Handayanto. 2018. Pengaruh PGPR (plant growth promoting rhizobacteri), Kapur, dan Kompos Pada Tanaman Kedelai di ultisol Cibinong, Bogor. J. Tanah dan Sumberdaya Lahan. 5 (1) : $629-635$.

Widarti, B. N., W. K. Wardhini, dan E. Sarwono. 2015. Pengaruh Rasio C/N Bahan Baku Pada Pembuatan Kompos Dari Kubis dan Kulit Pisang. J. Integrasi Proses. 5 (2) : $75-80$.

Widawati, S. 2015. Isolasi dan Aktivitas Plant Growth Promoting Rhizobacteria (Rhizobium, Azospirillum, Azotobacter, Pseudomonas) dari Tanah Perkebunan Karet, Lampung. J. Berita Biologi. 14 (1) : 77 - 88. 